\title{
De gRuYTen
}

G

DOI: $10.1515 / \mathrm{abcsj}-2016-0021$

\author{
'Global' Identity or the (Ir)Reducible Other: \\ The Cultural Logic of Global Identity \\ in Sir Arthur Conan Doyle's The Man with the Twisted Lip
}

JIN LEE

University of New Hampshire

\begin{abstract}
After the Syrian civil war, deaths of those fleeing crisis areas have tragically become a regular news item. Not new to the world, however, such crises emerge from tensions between identity and difference as codified in international politics, whereby refugees and migrants become the Other and subject to unyielding universals, such as the law or narrow concepts of what is right. Indeed, the cultural logic of "global identities" informing the current refugee and migrant crisis seems recurrent, as exemplified in the recent cases of the Tamils from Sri Lanka and the Somalis. The cultural logic of global identity is also reflected in the popular nineteenth-century novella by Sir Arthur Conan Doyle, The Man with the Twisted Lip, in which the main character disguises himself as a professional beggar to appeal to middle class values in order to incite their guilty consciences. Drawing on Ian Baucom, Marc Shell, and Jean-Joseph Goux, this article argues that the main character's actions reflect and embody the cultural logic of the global politico-economy in late nineteenth century London. As such, Doyle's novella illustrates the Derridean notion of hospitality by revealing that "identity and difference are mutually constitutive" (Baker 109) and offers insightful commentary on the current refugee and migrant crisis.
\end{abstract}

Keywords: Global identity, global trade, refugee crisis, hospitality, globalization, space-of-flow, Sir Arthur Conan Doyle, Thomas De Quincey, opium trade 
After the Syrian civil war, in 2015 alone, "two thousand five hundred people are estimated to have died while attempting to cross the Mediterranean" (Nordberg), and in May 2016, a headline telegraphically informed us: "three days, 700 deaths on Mediterranean" (Yardley and Pianigiani). At the center of the refugee or migrant crisis is a reduction of individuals to the Other, which reflects a history of tension between identity and difference in international politics ${ }^{1}$ as conducted on the basis of established law. Currently, for example, refugees and migrants are required to conform to European Union laws, in order to obtain universally accepted human rights. Ironically, however, national immigration policies within the EU only allow those within their borders who can afford to hire smugglers - itself a dangerous and risky practice whereas the less privileged, without resources or connections, must stay in their countries. As Jenny Nordberg reports, "the E.U. has tried to avoid granting prospective refugees [a basic human right] by making it nearly impossible for them to enter any of its countries legally." She further points out that since it is practically impossible for an Afghan to get a visa, s/he must "hir[e] smugglers" and spend "between ten thousand and eighteen thousand dollars per person," due to which it seems as if the EU were sending the message, “'We won't do anything to help you while you're on land, but once you risk your life, we will try to get there before you drown'" (Nordberg).

EU policy in this vein offers a Procrustean-bed solution that makes its guests fit their host's terms. Thus, Gideon Baker rightly observes that "hospitality ... has always been limited, offered subject to strict and domesticating conditionalities by a sovereign host" (109). That is, although rights and laws seem to be presented as universal, the "dialectical attempt to finally resolve the tension between identity and difference in world politics" is not universal, but "deeply particular" (Baker 115), as "the particular [is subsumed] within the universal" (Baker 108). In other words, the Procrustean irony of 'global identity' - as revealed in the national immigration policies of the EU - is that the 'global identity' of refugees and migrants flattens individuals into an Other, narrowly defined, thereby denying basic human rights to 
individuals who do not fit into the EU-defined Other. As such, global identity reveals cultural logic.

While it seems highly advisable to amend existing national immigration policies within the EU, it can prove just as worthwhile to examine the cultural logic of global identity informing this refugee and migrant crisis. Indeed, the cultural logic of global identity seems recurrent. Thus, in the late twentieth century, Tamils from Sri Lanka and Somalis became asylum seekers in the global North or neighboring countries by means of migrant smugglers and brokers (van Hear 179-80). Since the smugglers and brokers demanded remuneration, only those who could afford it were likely to get to affluent countries in Europe or North America, where they would be "better off than refugees in Pakistan and Iran" (van Hear 179).

The same cultural logic informing global identity emerges in a popular nineteenth-century British novella, Sir Arthur Conan Doyle's The Man with the Twisted Lip. When Sherlock Holmes uncovers the deception perpetrated by a country gentleman, Mr. Neville St. Clair, he reveals that St. Clair came to his wealth by disguising himself as a professional beggar, who was the beneficiary of donations from passersby. More importantly here, St. Clair profited by playing on middle class expectations and awakening their guilty consciences. In striking similarity to today's socio-economic values, Twisted Lip echoes Ian Baucom's observation regarding Thomas Pynchon's Mason and Dixon, that "the period of history in which we live should be understood either as an inordinately long twentieth century or as a very, very long eighteenth" (159). ${ }^{2}$ In this vein, I will abstract the cultural logic of global identity in Doyle's narrative in order to rethink the current refugee and migrant crisis. I argue that St. Clair is, in Pynchon's terms, a figure of "the doings of global trade in miniature" (qtd. in Baucom 158), reflecting and embodying the cultural logic of the global politico-economy in the late nineteenth-century London, the patterns of which we recognize today as well. Drawing on Marc Shell and Jean-Joseph Goux, I further argue that St. Clair and the British Empire are doubles. Lastly, by foreshadowing the current refugee and migrant crisis, Twisted Lip suggests the Derridean 
notion of hospitality as revealed in Britain's dependence on the Other in the opium trade.

\section{St. Clair as a Figure of "the Doings of Global Trade in Miniature"}

Doyle's Twisted Lip begins with the story of Isa Whitney, whose addiction to opium has advanced ever since college, when he read Thomas De Quincey's Confessions of an English Opium-Eater. Worried because he has been missing for two days, Mrs. Whitney asks Watson to find her husband, who is believed to be in an opium den in Upper Swandam Lane, where Watson does indeed find him. There, by chance Watson meets Sherlock Holmes, and both start work on finding another missing gentleman, St. Clair. While Susan Cannon Harris claims that "the crime in question has only the slightest of tangential relations with opiumsmoking" (460), the opium den is suggestive of a center of serious crimes. The beggar whom St. Clair impersonates, Hugh Boone, is suspected of the murder of St. Clair. Once St. Clair's fabrication is uncovered, Holmes agrees that he will not divulge St. Clair's deception, as long as he ends his double life, and thus, his family will continue to know him as a country gentleman. Considering that the opium den is the solution to both Watson's and Holmes' cases, the novella does after all suggest that St. Clair's 'crime' has a close relationship with opium-smoking, or, more specifically, with the global trade supporting opium-smoking and the opium den. In this manner, St. Clair's begging reflects what Baucom calls laws of global economy. As I will discuss in the next section, the proximity of St. Clair's business to Exchange Alley, the East India Company, and the opium den is significant, ${ }^{3}$ as this location enables St. Clair to tap into the surplus cash in spaces-of-flows, which identify buildings or areas critical to financial transactions.

In "Globalit, Inc.; or, The Cultural Logic of Global Literary Studies," Baucom traces patterns in what he perceives as "the form of the global" (159). Beginning with a question Thomas Pynchon's Mason and Dixon ask, "why has ev'ry Observation site proposed by the Royal Society prov'd to be a Factory, or Consulate, or other Agency of some 
royally Charter'd Company?"' (qtd. in Baucom 158), Baucom suggests two analogies between the late eighteenth century and the late twentieth century, and global capital and global literary studies. According to him, many scholars have recently discussed the first analogy between the late eighteenth and the late twentieth century. For instance, in Baucom's reading, Giovani Arrighi recognizes that the same "fundamental logic and effect of ... structures" in chartered companies and transnational corporations can be found in the way "New York replaces London, which replaces Amsterdam as the center of global finance capital" (160). Based on Arrighi's observation of the repetition of this global form in the last three hundred years, Baucom makes a bold claim that "the analogy ... between then and now is not an analogy at all but an eternal recurrence" (160). For the second analogy between global capital and global literary studies, Baucom poses that Frederic Jameson's The Political Unconscious can be viewed as a rewriting of Walter Scott, one that shows "extraordinary influence on the development of a quasi-global method of literary study" as well as "a neo-Romantic response to the problems of global capital and global form" (161). For the purposes of this article, I will focus on "the global process to which Scott was responding" (Baucom 162), as it can help explain ways in which literature intersects with global capital in St. Clair's London.

Baucom sums up the global processes in Scotland based on his reading of Ronald Meek and Walter Scott as follows. First, "the reorganization of global capital" transformed Glasgow "as one of the globe's spaces of flows" (Baucom 161-2). Through this process, "the Lowlands city linked itself to, and concentrated in itself the wealth of, an expanding series of capital horizons: primary among them the Highlands (through the confiscation and enclosure of sheep-farming lands), North America (by the tobacco plantations), and Africa (by the slave trade)" (Baucom 162). Second, the underdeveloped areas in the developed regions, what Baucom would call "temporal irregularities" (161), could be understood as a "spectral counternarrative of the global" or "cultural haunting" in which the Highlands, Africa, and North America return to the Lowlands metropolitan entrepôts (162). 
The global processes Baucom discusses in connection with Scotland seem to take place in St. Clair's London as well. In Twisted Lip, for example, London has "temporal irregularities" (Baucom 161) similar to Meek's discussion of the map of Scotland. That is, London was divided into spatially and temporally different areas according to their economic development. This becomes obvious in Doyle's narrative, when Mrs. St. Clair declared she "did not like the neighbourhood" around the opium den, which contrasts with the area around the "offices of the Aberdeen Shipping Company" (10). As such, Baucom's three laws - expansion contracts, contraction enriches, and enrichment haunts - play out in Twisted Lip as well. The opium den is supposedly located in the East End, which "from the earliest times ... has been associated with the great blight of London poverty" (Ackroyd xii). From its poverty, the East End points to the business part of the city, which "linked itself to, and concentrated in itself the wealth of, an expanding series of capital horizons," making the East End analogous to the British colonies. The East End and the opium den further illustrate Baucom's law of global economy, "enrichment haunts" (162). That is, the business district of the city expands its capital horizons and concentrates the wealth, while the East End, "'a microcosm of London's past"' (Ackroyd xii), and the opium den in St. Clair's London, illustrate "the haunting return of difference" (Baucom 162), as, for instance, when Britain's colonies are implied as a Malay attends customers, and a Lascar manages the business. In this manner, Baucom's three laws of global economy is applicable to Twisted Lip.

\section{The Opium Den and St. Clair Tapping into the Spaces-of-Flows}

The possible locations of St. Clair's "begging business" and the opium den seem to be near Exchange Alley, and thereby constitute what Giovanni Arrighi and John Ruggie call "spaces-of-flows," which are

spaces that are linked to the furthest corners of the earth but that belong less to the city or state in which they happen to have come to rest than to the principles of exchange they embody, the "flows of precious metals, bills of exchange [...] monetary surpluses" they regulate, the conversion of endless variety into a single, general equivalent: money (82-83). The 
Bourse in Amsterdam, Exchange Alley in London, Wall Street in New York are, for Arrighi, the form the global has repeatedly taken over the past three hundred years, the form, one might suggest, of an end of history that happens not once but serially... (Baucom 160)

In Twisted Lip, St. Clair describes his movement in the city as follows. He "took [his] station in the business part of the city, ostensibly as a matchseller but really as a beggar" (Doyle 10). Further, he lodged in the opium den in Upper Swandam Lane, and "could every morning emerge as a squalid beggar and in the evenings transform [him]self into a well-dressed man about town" (Doyle 10). Moreover, according to Watson, "Upper Swandam Lane is a vile alley lurking behind the high wharves which line the north side of the river to the east of London Bridge" (Doyle 1), and the opium den is, as Holmes explains, "'near the corner of Paul's Wharf" (Doyle 3). Further, Mrs. St. Clair reports, the opium den was on her way from the office of the Aberdeen Shipping Company to the station (Doyle 4). With these clues and the help of a map of "London in the $19^{\text {th }}$ and $20^{\text {th }}$ Centuries" found on the website of the Norton Anthology of English Literature, it is possible to approximate where the opium den and St. Clair's station could have been in the nineteenth-century London.

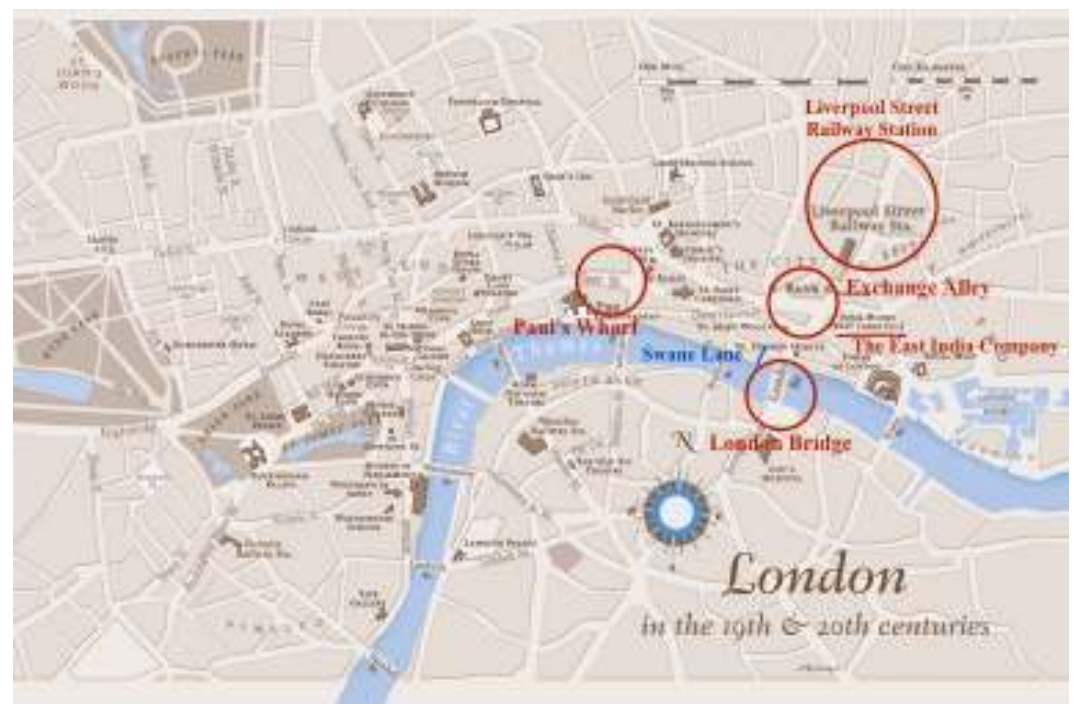

Figure 1. The Map, "London in the $19^{\text {th }}$ and $20^{\text {th }}$ Centuries" 4 
Doyle, of course, could have made up everything regarding the location of the opium den and St. Clair's begging station: the distance between Paul's Wharf and London Bridge seems quite farther than implied in the novella. Moreover, the opium den "in the farthest east of the City" (Doyle 1) may not be located in East End. ${ }^{5}$ Yet, those who lived in London of the nineteenth century might have imagined where this opium den and St. Clair's begging station could have been. Since Upper Swandam Lane could have been Swan Lane, which is right next to London Bridge, ${ }^{6}$ the route Mrs. St. Clair could have taken to get to the shipping company from the station could be from Liverpool Street Railway Station through Exchange Alley and past The East India Company to the opium den, near London Bridge. What is significant is that the shipping company as well as "the business part of the city" (Doyle 10), where St. Clair begged, could be near Exchange Alley and The East India Company.

Thus, Exchange Alley as a space-of-flow is "linked to the furthest corners of the earth but ... belong[s] less to the city or state in which [it] happen[s] to have come to rest." The description could apply to the opium den in that it has a perhaps imaginary geographical location near Exchange Alley, but also because opium can create an imaginary space which does not belong to London or any part of the physical world. ${ }^{7}$ Doyle's opium den is "an alien environment ... [and his] description of the opium den reflects the fear that, instead of creating Gladstone's 'happy Englands' (Gladstone 202) abroad, the Empire was allowing China to recreate its opium-induced miseries at home" (Harris 455). ${ }^{8}$ This seems very much like Baucom's law that enrichment haunts.

Doyle is not alone in describing the opium den in this manner. De Quincey in Suspiria de Profundis describes this imaginary, narcotic, "terrifyingly alien" space "of suspended autonomy," (Krishnan 204), as "some separate chamber in [one's] brain" (qtd. in Krishnan 204). Indeed, De Quincey hallucinates so much so that London seems to be "some of these terrae incognitae" (De Quincey 25, italics in the original), which "is likened to an arctic region through which 'ambitious' explorers navigate with hopes of discovering a quicker route from Europe to Asia" (Krishnan 207). Thus, opium "transport[s]" the opium eater to "Asiatic scenes," even 
while he is at home (De Quincey 38). As "the vector of the narcotic pushes the self [De Quincey] toward the terrors and possibilities opened up by difference" (Krishnan 205), it is probably this aspect (which Zieger calls "De Quinceyan exotic mental voyaging" [1532]) that the first missing husband, Whitney, wished to achieve in the opium den: "for having read De Quincey's description of his dreams and sensations, he had drenched his tobacco with laudanum in an attempt to produce the same effects" (Doyle 1). Further underscoring the exotic space that "belong[s] less to the city" of London than "the furthest corners of the earth," it is "a sallow Malay" (Doyle 2) who attends customers and "the rascally Lascar" (3) who runs the business in the opium den.

\section{Baucom, and Global Literature, and Global Capital in De Quincey and St. Clair}

By means of Whitney's explicit reference to De Quincey, then, the opium den and all its associations in Twisted Lip are significantly related to "De Quinceyan exotic voyaging" in an imaginary, liminal space. Since the city of De Quincey's hallucinated vision in Confessions intersects with that of global commerce, the opium den is also related to the global economy. De Quincey uses geographical terms for exploration and international trade such as "north-west passage" and "terrae incognitae" while describing his experience of walking in London under the influence of opium:

...sometimes in my attempts to steer homewards, upon nautical principles, by fixing my eye on the pole-star, and seeking ambitiously for a north-west passage, instead of circumnavigating all the capes and head-lands I had doubled in my outward voyage, I came suddenly upon such knotty problems of alleys, such enigmatical entries, and such sphynx's riddles of streets without thoroughfares. ... I could almost have believed at times that I must be the first discoverer of some of these terrae incognitae, and doubted whether they had yet been laid down in the modern charts of London. (De Quincey 25, my italics)

In regards to these words, Sanjay Krishnan argues that "the relocation of London to the frozen waters to the north of Canada and Alaska is authorized by the reference to the elusive 'Northwest Passage,' which 
stood in the collective imagination of English traders of the time as code for the vast markets for opium in Asia" (207). It is worth noting that even De Quincey's narcotic vision comprises the collective imagination of English trades of the time, and that what he was seeking, a north-west passage, would lead him to global markets for opium. This imaginary, narcotic space is likened to a place of commerce of some sort in Suspiria de Profundis: "The dreamer finds housed within himself ... holding, perhaps from that station a secret and detestable commerce with his own heart - some horrid alien nature" (qtd. in Krishnan 204, my italics).

For De Quincey, this "commerce with his own heart" turns out to benefit not only his literary profession but also his national economy by means of the power of literary imagination. While he "stressed [opium] did not create anything new but embellished what already existed, heightening awareness of latent thoughts and imagination" (Booth 36), De Quincey seems to have benefited from opium in terms of his literary profession. Not only De Quincey, but "a substantial number of creative artists ... were also addicted and ... through their addiction, changed the direction of Western literature" (Booth 40). Further, in a different context, De Quincey advocated not physical but imaginative invasion of China when he supported the Opium War with China, again underscoring Baucom's law that enrichment haunts:

...what is needed, [De Quincey] says, is not a physical invasion of Chinese territory, but an imaginative invasion of the Chinese mind; not violence, but the representation of potential violence. The poetic effect adverted to here is the Sublime of terror, where the withholding of any physical threat to the observer defeats his inclination to resist the "impression" of annihilative power, thus enabling that impression to extend and secure its control over his imagination. (Rzepka 43)

While the Opium War would fix the "alarming hemorrhage of funds" caused by the trade with China by "restoring equilibrium and generating a surplus of dynamic power" (Krishnan 209), De Quincey emphasizes the power of literary imagination to bring about the desired effects on the trade with China.

Framed in the global economy, De Quincey's narcotic literary vision recurs in Doyle's novella when St. Clair dreams of financial 
success, takes advantage of "the business part of the city," and taps into the surplus cash in the spaces-of-flows. Whereas De Quincey uses the power of literature to support his national economy, St. Clair deploys his imaginative power to support his domestic economy. Although he says he pretended to be "a match-seller but really [was] a beggar," St. Clair was actually a business man who used his skills in disguise and repartee (Doyle 10). While "offering the public an experience that conflates charity with entertainment" (Marck 109), St. Clair "has created a new profession ... [He] offers an early version of street theatre not far removed from the performances of modern buskers" (Marck 111). In other words, St. Clair exchanges a sense of charity and entertainment for coins, as encouraged by his pitiable appearance and repartee. Unwittingly, passersby in the

space of flow (i.e. the business district) engaged in this trade. For being entertained by the beggar as well as feeling good about their acts of charity, they give money to St. Clair.

Shell and Goux: Commercial Language and the Notion of Old Value in St. Clair's Begging Business

In addition to the analogy between global capital and global literature that Baucom suggests, St. Clair's trade between charity and entertainment, in particular, goes beyond that analogy. Indeed, with regard to St. Clair's repartee, it is his literary skill that becomes exchangeable for money. That is, the relation between literature and economy is more than analogous. In this vein, St. Clair's use of literary trope and verbal skill may be best understood in Shell's terms. In The Economy of Literature, Shell makes a bolder claim that is more than an analogy, to discuss "the relation between ... literary exchanges and the exchanges that constitute the political economy" (7). He argues that "[1]iterary works are composed of small tropic exchanges or metaphors, some of which can be analyzed in terms of signified economic content and all of which can be analyzed in terms of economic form" (7). Thus, in Chapter 4, "The Lie of the Fox: Rousseau's Theory of Verbal, Monetary, and Political Representation," Shell explains Rousseau's reading of Aesop's fable, "The Fox and the Crow," along these lines: The hungry Fox approaches the Crow and flatters him about 
his voice, who starts to sing. As he does so, the Crow loses the cheese he held in his beak, and the Fox says, "'Learn that every flatterer. / Lives at the expense of him who listens. / This lesson is worth a cheese, without doubt"' (qtd. in Shell 115). While Shell makes various points, I will focus on his argument that commercial characters are "a common measure ... of all commodities" (123) to discuss St. Clair's repartee and disguise as a commercial language. In Marc Shell's terms, St. Clair's words, which reflect his "excellent education" (Doyle 10), act like "a common measure."

In The Economy of Literature, Shell discusses the close relationship between alphabets and a monetary economy, particularly as found in commercial language. Thus, he attributes to Rousseau the idea that "the historical development of the alphabet corresponds to that of a monetary economy and to that of a police state," which "explains the origin of commercial language and, perhaps, what we call 'commercials," in part because merchants travelling to several countries would have to invent characters that could be understood by all (123). Shell further explicates how these "characters are like money, which is a common measure not of all languages (as the alphabet) but of all commodities," since they "are common measures of sounds, or alphabetical symbols, that permit translation through signs of sounds of words" (123, my italics). He then goes on to compare monetary characters with alphabetical characters: "Monetary characters permit the translation of these commodities; similarly, alphabetical characters (and puns) permit the sonal representation of two languages in one medium" (123).

In this sense, St. Clair's business takes advantage of what Shell, by means of one of Aesop's fables, explains as "the terrifying common denominator that makes possible the economic exchange of flattering words (which the fox gives) for objects (which the fox receives)" in Aesop's fable (119). Referring to Rousseau's discussion of the fable, Shell argues that "The fox, having well digested the power of the double entendre, turns out to be an excellent poet. He makes language, alien and alienating, serve his own ends, as did the Greek sophists. Like Gyges, he is the banker-tyrant of the modern world" (123, italics in the original). In other words, the fox who flatters (and lies) about the crow's appearance 
and voice, makes the crow confuse nature (the signified) with words (the signifier). The fox's flattery (i.e., a commercial intended to swap his words with the cheese) becomes exchangeable for the cheese, thereby working like money, "a common measure ... of all commodities." Likewise, St. Clair's disguise and repartee produce effects similar to those of a commercial intended to encourage people to be good to a pitiable person. In other words, St. Clair creates a demand in the charity market to create what Gary Shapiro calls an "asymmetric relationship of giver and receiver" (281). ${ }^{9}$ Simply put, St. Clair creates the opportunity to exchange charity for coins.

What is involved in the exchange, however, is more complex. Thus, St. Clair's performance comprises symbols understood by all those involved in a business transaction; he partakes of a commercial language, one that involves money. Importantly, his words and disguise are common measures not of all languages but of the language of the middle class. As Nancy Anne Marck points out, "His portrayal of Hugh Boone offers a middle-class interpretation of begging that romanticizes and exoticizes poverty and dependence, an interpretation that evades the reality of the beggar by treating it as a stage role" (108). Therefore, "few beggars could compete with the likes of Hugh Boone" since "St. Clair's financial success results directly from his connection to the [middle] class he evades through disguise" (Marck 108). That is, with his bedraggled appearance and his witty repartee, St. Clair communicates not as real beggars would, but in a manner that is appealing and understandable to those with a middle-class mind set.

Shell's discussion of Rousseau's reading of Aesop's fable further suggests the possibly inherent exploitation in St. Clair's business. Shell argues:

The récit of the fox in "Le Corbeau et le renard" is a clever exchange of words for cheese that sustains the fox's life and crafty nature. Rousseau suggests that bad tutors and even La Fontaine [the translator] himself are exploiters like the fox. The fox's claim that his leçon is worth a cheese is, on a level deeper, perhaps, than La Fontaine's irony, a claim that the fable itself contains a worthy leçon.

La Fontaine's fable (like the fox's récit) turns out to be a kind of merchandise. It is a commodity to be exchanged for something else. At 
the same time it is a process of apparently counterfeit linguistic metaphors, or purchases and sales of meanings. (126, italics in the original)

Just as the Fox's trickery exploits the Crow to obtain his cheese, St. Clair's false representation of a disabled beggar deceives passersby and exploits them to obtain their money, while pretending that his physical condition is worthy of their charity. By becoming "a recognizable character in the City" (Doyle 10), he does what Arrighi observes in chartered companies, which "monitor, regulate, and profit from the disequilibria of world trade" (qtd. in Baucom 159). While St. Clair regulates the flow of surplus coins in the businessmen's pockets by attracting his charitable customers from other competitors (e.g., beggars), he taps into the "profit[s] from the disequilibria of world trade," which circulate in the financial district of the city, the space-of-flow. In the terms Baucom borrows from Thomas Pynchon, St. Clair is one of "the doings of global trade in miniature" (qtd. in Baucom 158). If Exchange Alley is "the form the global has repeatedly taken over the past three hundred years" (Baucom 160) and the chartered company as a figure, in Baucom's terms, "permits us to imagine and name the forms that capital takes in a moment of globalization" (159), then St. Clair is such a figure as well.

Shell's reading of "The Fox and the Crow" helps us better understand St. Clair's use of commercial language in his begging business and his "doings of the global trade in miniature," but it does not quite explain the fact that both St. Clair's charitable passersby and Aesop's Crow were not aware that they were in fact trading respectively with St. Clair and the Fox. What appears to be non-financial transactions, however, can be explained using Jean-Joseph Goux's terms: St. Clair's business presents the premonetary symbols at face value while desegregating "a notion of economic value" (126) from the symbol and reattaching the symbol to "the old notion of value" (126). Aesop's Crow as discussed by Shell thus proves to be an example of Goux's "old notion of value," and resembles the charitable passersby who give money to St. Clair.

In Symbolic Economies, Goux explains Louis Gernet's "premonetary conception of value" and Jean-Pierre Vernant's "“rational 
contrivance' of legal tender" (126). The premonetary conception of value - as in "the mythical notion of value in ancient Greece" - established "[c]ertain luxury items, such as vases, jewels, clothing, and tripods ... as instruments of exchange in a noble form of trade" (Goux 126). The economic value of these items "remained integrated with the supernatural virtues imagined to be inherent in it" (Goux 126). Therefore, these objects would signify "not only wealth but sacred powers, social prestige, and ties of interpersonal dependence" (Goux 126). In contrast, in modern society, "'the rational contrivance' of legal tender [is] backed by allowing the old notion of value, charged with affective powers and religious assumptions, to be replaced by a notion of economic value which is free from interference, from the static of valorizing dimensions" (Goux 126, my italics).

The history of this symbolism demonstrates that "currency introduces a segregation of values, setting economic value cleanly apart" (Goux 126). In contrast, St. Clair's business appeals to "the old notion of value." In other words, charity has not only economic value to the beggar and the giver, but also additional values, including those like religious duty and noblesse oblige, along with, as Goux observes, "social prestige, and ties of interpersonal dependence" (126). In sync with the desegregation of the old notion of value from begging, ${ }^{10}$ St. Clair's strategy to evoke pity and terror - "inspiring pity by my ghastly face" (Doyle 10) was timely in that " $[t]$ hroughout the first half of the nineteenth century all British governments were haunted, in varying degree, by the bogey of French Jacobinism" and "the nightmare of an angry mob sweeping into the capital from its poorest quarters continued to disturb the comfortable assurance of Victorian minds" (Palmer 74). As Marck underscores, St. Clair uses "the skill of make-up ... to convert middle class guilt into cash as Hugh Boone" (108).

The real lesson of "The Fox and the Crow," then, is not "every flatterer / Lives at the expense of him who listens" (qtd. in Shell 115), but that the old notion of value becomes less available when trading with currency, which segregates values. Based on the anti-opium propaganda, which presents the old notion of value, however, nineteenth-century Britain did not seem to learn this lesson from Aesop's fable. 


\section{Where Literature Intersects with Global Politico-Economy: How St. Clair Reflects the British Empire's Strategy}

When Hugh Boone's real identity as St. Clair is exposed, he makes an appeal to pity to avoid public exposure. St. Clair says to Holmes, "'God help me, I would not have [my children] ashamed of their father. My God! What an exposure! What can I do?"” (Doyle 9-10). St. Clair's appeal demonstrates that at the time, the "[l]aw, toxicology, and anti-opium propaganda brought opium and other narcotics into the category of poisons" (Harris 452). Categorizing opium as a poison could inspire pity, that is, because England is a victim, not a victimizer: "England is strung out on opium and cannot be held responsible for its actions" (Harris 455). Following Barry Milligan, Harris argues that, "when opium entered British discourse it quickly became a symbol of corruption and contagion" (453). It became a poison, a symbol of "alien contagion" (qtd. in Harris 449) later in the nineteenth century, "when anti-opium activists use[d] the drug itself to symbolize the moral corruption to which this imperial policy was exposing England" (Harris 454). "[T]he construction of opium as poison" gives the public a good excuse for the effects of the opium trade, since it "helps allay them by attaching the moral blight associated with the opium trade to the drug itself, which can then be reattached to the Orient.... The 'incredible' fact that 'the British Government is actually implicated in such a trade' (British Opium 3) thus becomes explicable" (Harris 454-55). The same rhetoric recurs in De Quincey's Confessions as well: "This inhabitation of the position of feminized victim is crucial to De Quincey's portrayal of himself: the English opium-eater is, above all, one who suffers. Moreover, this construction of autobiographical subjectivity lays the groundwork for a similar construction of English national identity" (Schmitt 68).

While Marck reads St. Clair and Holmes as "doubles" for the ways in which both use disguise and "exercise their own extraordinary creative abilities" (115), there are more doublings than Marck observes: De Quincey and Whitney as well as that involving St. Clair and the British Empire. Thus, like De Quincey, whose influence was directly cited, Whitney too is pitiable and "cannot be held responsible for his addiction." 
Likewise, while not addicted to opium itself, St. Clair is addicted to begging in order to maintain his lifestyle as a suburban gentleman, so much so that he fears public exposure. It is not a coincidence that St. Clair's concern about his honor and reputation for his children's sake echoes that of the British Empire; "F.S. Turner's critique of the opium trade reflects not so much concern for China's welfare as profound anxiety about Britain's threatened claim to moral superiority" (Harris 454). The British Empire is concerned about its national image, about its honor and reputation.

Harris makes the point that "Holmes proves ... the contagion the crime seems to imply never, in fact, existed" (460), which makes sense. Nonetheless, the crime's seemingly "tangential relations with opiumsmoking" (Harris 460) suggests that St. Clair's business's proximity to and similarity to that of the opium den and The East India Company gives weight to understanding St. Clair's economic symbolism as more central. Baucom's reading of global capital and global literary studies could suggest a way to navigate through the irregularities in the map of London, described above, recurring with the same logic as found in the global processes in Meek and Scott. Shell's study helped to read commercial language in St. Clair's begging business, and tie it to the law of global economy as found in Baucom. Goux's point about the "old notion of value" in premonetary symbols enabled linking the use of Baucom's and Shell's ideas through the economic trade structure of St. Clair's begging business. All in all, St. Clair turns out to be one of "the doings of global trade in miniature," reflecting and embodying the global politico-economy in the late nineteenth-century London.

\section{Global 'Identity,' the (Ir)Reducible Other, and Radical Hospitality}

Significantly, Inspector Bradstreet acquits and releases St. Clair with a warning that "If the police are to hush this thing up, there must be no more of Hugh Boone" (Doyle 11). By reducing the difference in St. Clair/ Hugh Boone to the "identity" of a British gentleman, Doyle subsumes the Otherness or the particular into the universal, British 
identity, and thereby safely closes the case. In so doing, Doyle also closes his eyes to St. Clair's "doings of global trade in miniature," which mirrors his double, the British Empire's dependence on the Other in the global trade. Although Doyle thus marginalizes the British Empire's dependence on the Other, Twisted Lip nonetheless discloses what Baker would call Britain's "radically decentering experience of the Other and of dependence on the Other" (117). As St. Clair relied on his "confederate" (Doyle 5), the Lascar manager of the opium den, so that St. Clair could disguise himself as Hugh Boone in the opium den and keep running his begging business, so too the British Empire relied on China and India in the opium trade. As a liminal figure, St. Clair implicates the Other in his trade as well as standing between the Same and the Other, revealing that "identity and difference are mutually constitutive" (Baker 109). Doyle's fiction thus prophetically speaks to the current refugee and migrant crisis and suggests Jacques Derrida's unconditional hospitality. Derridean unconditional hospitality is based on Emmanuel Levinas' "subjectivity [that] stems from the ego's awareness that it is not sovereign but exists in a world that, far from being an extension of or coinciding with itself, it is fully dependent on" (Baker 117).

While the British middle class members reduce individuals to the Other in their limited terms of who are in need, they find themselves unwittingly patronizing St. Clair and encouraging St. Clair to become a beggar, leaving us to rethink who might be left out from those rescued in the current refugee and migrant crisis. A Derridean approach allows us to appreciate the dynamic between hospitality and those deemed to be in need. This approach may lead us to fully investigate the global logic which now prevails.

\section{Notes:}

\footnotetext{
${ }^{1}$ With regard to "the tension between identity and difference in world politics," see Baker 115.

${ }^{2}$ Here, Baucom seems to draw on Fernand Braudel's notion of longue durée or structural time. Braudel "criticized 'event-dominated' or episodic history" and "the search for timeless, eternal truths," whereas he "insisted on two other social times ... structural time (or long-lasting, but not eternal, basic structures that underlay historical systems), and the cyclical processes within the structures (or
} 
medium-run trends, such as the expansions and contractions of the worldeconomy)." See Wallerstein 15.

${ }^{3}$ As Marck shows, Michael Atkinson also locates St. Clair's station near the Bank of England, itself near Exchange Alley: "Atkinson notes the proximity of Boone's begging location in Threadneedle Street to the Bank of England" (Marck 109).

${ }^{4}$ After checking Google and other maps of $19^{\text {th }}$ century London on the internet, I estimated where Paul's Wharf, Swan Lane, and Exchange Alley could be and entered them on the map provided by the Norton Anthology, by use of red and blue letters.

${ }^{5}$ From the maps in Alan Palmer's The East End, the East End starts approximately at the London Docks.

${ }^{6}$ The existence of Old Swan Wharf, east of Swan Lane, dates back to 1848-51, at the latest (Harben), and Swan Lane is close to London Bridge. Therefore, it is plausible that Upper Swandam Lane could have been Swan Lane.

${ }^{7}$ Susan Zieger argues that "[Fitz Hugh] Ludlow's and other's autobiographies illuminate how the hallucinatory inner space of subjectivity engaged the imperial tropes of travel, exploration, and conquest that governed nineteenth-century conceptualizations of geographic space" (1531).

${ }^{8}$ The description of the opium den in Twisted Lip that Harris analyzes is as follows: "Between a slop shop and a gin shop, approached by a steep flight of steps leading down to a black gap like the mouth of a cave, I found the den of which I was in search.... [B]y the light of a flickering oil lamp above the door I found the latch and made my way into a long, low room, thick and heavy with the brown opium smoke, and terraced with wooden berths, like the forecastle of an immigrant ship" (Doyle 1).

${ }^{9}$ Based on Nietzsche, Shapiro observes that "[w] hen one gives alms, for which one expects no return whatsoever, one humiliates the objects of one's charity by placing them in a situation that emphasizes their impotence and incapacity" (281). In St. Clair's case, he could have taken advantage of this aspect to give his customers a sense of superiority.

${ }^{10} \mathrm{I}$ read St. Clair's disguise as a disabled beggar as signifying his disassociating the conventional notion of value from business, since he presents his begging as for charity, not for a business.

\section{Works Cited}

Ackroyd, Peter. Introduction. The East End: Four Centuries of London Life. By Alan Palmer. New Brunswick, NJ: Rutgers UP, 2000. xi-xvi.

Baker, Gideon. "Cosmopolitanism as Hospitality: Revisiting Identity and Difference in Cosmopolitanism." Alternatives: Global, Local, Political 34.2 (Apr.-June 2009): 107-28. 
Baucom, Ian. "Globalit, Inc.; or, The Cultural Logic of Global Literary Studies." PMLA 116.1 (Jan. 2001): 158-72.

Booth, Martin. Opium: A History. New York: St. Martin's Press, 1998.

Critchley, Simon and Richard Kearney. Preface. On Cosmopolitanism and Forgiveness. By Jacques Derrida. London and New York: Routledge, 2001. vii-xii.

De Quincey, Thomas. Confessions of an English Opium-Eater. Champaign, Ill: Project Gutenberg, n.d. eBook Collection (EBSCOhost). Web. 4 Sept. 2013.

Derrida, Jacques. Adieu to Emmanuel Levinas. Trans. Pascale-Anne Brault and Michael Nass. Stanford: Stanford UP, 1997.

---. On Cosmopolitanism and Forgiveness. Trans. Mark Dooley and Michael Hughes. London and New York: Routledge, 2001. Print.

Doyle, Arthur Conan. The Man with the Twisted Lip. The Complete Sherlock Holmes Canon. March 15 2014. Web. 12 May 2016.

Harben, Henry A. "Old Swan Wharf - Olivaunt." British History Online. British History Online, n.d. Web. 19 March 2016.

Harris, Susan Cannon. "Pathological Possibilities: Contagion and Empire in Doyle's Sherlock Holmes Stories." Victorian Literature and Culture 31.2 (2003): 447-66.

van Hear, Nicholas. "Refugees, Diasporas, and Transnationalism." The Oxford Handbook of Refugee and Forced Migration Studies, edited by Elena Fiddian-Quasmiyeh, Gil Loescher, Katy Long, and Nando Sigona, Oxford: Oxford UP, 2014. 176-87.

Goux, Jean-Joseph. "Exchange Value and the History of the Symbolic." Symbolic Economies: After Marx and Freud. Ithaca, N.Y.: Cornell UP, 1990. 12233.

Krishnan, Sanjay. "Opium and Empire: The Transports of Thomas de Quincey." Boundary 233.2 (2006): 203-43.

"London in the $19^{\text {th }}$ and $20^{\text {th }}$ Centuries." Digital image. Map. Scale not given. W.W. Norton \& Company. Inc. W.W. Norton \& Company Inc., n.d. Web. 12 May 2016.

Marck, Nancy Anne. "Drugs, Doubling, and Disguise: Sherlock Holmes and 'The Man with the Twisted Lip'." Unrespectable ReCreations (2001): 107-116.

Nordberg, Jenny. "Europe's Crisis of Conscience." The New Yorker, 11 Sept. 2015. Web. 19 Oct. 2016.

Palmer, Alan. The East End: Four Centuries of London Life. New Brunswick, NJ: Rutgers UP, 2000.

Rzepka, Charles. "The Literature of Power and the Imperial Will: De Quincey's Opium War Essays.” South Central Review 8.1 (Spring 1991): 37-45.

Schmitt, Cannon. "Narrating National Addictions: De Quincey, Opium, and Tea." High Anxieties: Cultural Studies in Addiction (2002): 63-84.

Shell, Marc. The Economy of Literature. Baltimore and London: The Johns Hopkins UP, 1978. 
Shapiro, Gary. "The Metaphysics of Presents: Nietzsche's Gift, the Debt to Emerson, Heidegger's Values." The Logic of Gift. By Alan D. Schrift. London: Routledge, 1997. 274-91.

Wallerstein, Immanuel. World-Systems Analysis: An Introduction. Durham and London: Duke UP, 2004.

Yardley, Jim, and Gaia Pianigiani. "Three Days, 700 Deaths on Mediterranean as Migrant Crisis Flares.” The New York Times, 30 May 2016. Web. 19 Oct. 2016.

Zieger, Susan. "Pioneers of Inner Space: Drug Autobiography and Manifest Destiny." PMLA 122.5 (2007): 1531-47. 